\title{
Improving Navel orange (Citrus sinensis L) productivity in Delta Region, Egypt
}

\author{
Waleed Abobatta \\ Agriculture Research Center, Egypt
}

Correspondence: Waleed Abobatta,Agriculture Research Center, 9 Gamaa, Egypt, Tel +201224296948, Email wabobatta@yahoo.com Received: February 02, 2018 | Published: February I5, 2018

Copyright@ 2018 Abobatta. This is an open access article distributed under the terms of the Creative Commons Attribution License, which permits unrestricted use, distribution, and reproduction in any medium, provided the original author and source are credited.

\begin{abstract}
Summary
The objective of this work presents general information about the Washington Navel sweet orange cultivar (Citrus sinensis L.) productivity in Delta region, Egypt, over the next few years, focusing on increasing total yield and enhancement fruit quality by following good agricultural practices, and increasing alertness among growers of the need for implement fruit quality to compete in the global market. Some of the practices include usingproper fertilizers, irrigation technique, pruning, integrated pest management and harvest technique.
\end{abstract}

Keywords: navel orange, citrus sinensis, yield, fruit quality, delta region.

\section{Introduction}

Citrus trees occupy a significant economic importance among fruit crops in Egypt regarding cultivated area, production and exportation potentialities; also, it is the largest horticultural industry, Egypt considered the largest orange exporter in the world and ranking as the sixth largest producer. Orange is the main citrus species in Egypt, where the area of cultivated about 133,236 hectares representing about $69 \%$ of the total citrus area, producing about 2.9 million tons, representing about $71 \%$ of the total citrus production, exports orange about 1.1 million tons, representing about $92 \%$ of the total amount of total citrus exports.

\section{Problem statement}

There are different problems of navel orange productivity in the Delta region like:

1. Poor irrigation technique mostly used excessive quantities of water without a proper irrigation system.

2. Lack of appropriate amount of fertilizers, also, mostly there's no recommended fertilization programs

3. There are wide areas had low productivity due to the tree sinensis, some of this orchards planting more than 50 years ago.

4. Low productivity of different orchards (around 22 tons/ ha).

5. Planting distance vary from $4 \times 6,3 \times 5,3 \times 6$ even $2 \times 3$ in some areas.

6. Most of the orchards in Delta region have mixed varieties within the same field.

7. Sour orange (Citrus aurantium L) considered the main rootstock utilized in Delta region and mainly affected by soil pathogen like Phytophthora root rot.

8. Local wholesaler and retailer prices are very low compared to other fruits.

\section{Cultivated area}

Orange considered is the main cultivated species among citrus varieties in Egypt, also, orange almost is planted in all of the Egyptian governorates. However, most of the Navel orange planted area is concentrated in the Delta governorates (Gharbia, Qalyoubia, Menoufia, Sharqiya, and Ismailia) which considered the main producing areas.

Navel oranges are the predominant variety of citrus all over Egypt and especially in Delta region, also, Navel orange rank the first position between citrus crop and representing 60 percent of all cultivated area and 60 percent of the total orange production. ${ }^{1}$

From another side, Navel orange is the most favorite cultivar in Egypt and it is considered the popular fresh citrus fruits for the Egyptians due to its seedless, large size and flavor and aroma characteristic, fruit high quality, desirable taste and low prices compared to other fruits, Navel orange is the main source of early season income for citrus growers in Delta region.

\section{Productivity}

Egypt is one of the world's leading orange producers and exporters rank as the sixth orange producer in the world after Brazil, China, USA, EU, and Mexico. Oranges represent around 30 percent of the total Egyptian fruit production and 65 percent of citrus production. 
Orange cultivated area in 2016 reaches 133, 236 hectares producing about 2.90 million tons, and Egypt's proximity to major importing countries.

Even though the deterioration of old farms in the various Delta governorates for different reasons there are good chance for Egyptian Navel orange growers to increase yielding and fruit quality due to the availability of irrigation water, appropriate climatic conditions, fertile soil, low labor costs, an early harvest time compared to other producers in the world.

\section{Orange verities}

Several orange varieties are produced in Egypt but the main varieties are six, Navel and Valencia are the major export varieties while the others are used more for domestic consumption.

While, Navel orange considered the main variety produced in Delta region, however, there are other varieties like Baladi Orange, Blood orange, Khalily orange and Sweet Orange (Sukkari) but in small areas.

\section{Implementation navel orange productivity in delta region}

Navel orange orchard management requires an understanding of physiology and crop phenological stages, wherever appropriate practice and enhancement of management activities improve the total yields which increase the final income for growers.

\section{Nutrient management}

In the Nile delta region, where water and fertile grounds are available and just need good practice to manage nutrient applications like soil testing, tissue testing to the determined amount of different fertilizers according to trees requirements, ${ }^{2}$ also, preferable splitting nutrient doses, and using proper application techniques

Nutrition management considered an important part of agricultural performs that reduce pollution soil and groundwater resources, help protect the environment and though, and keeping of different natural resources. Proper nutrient management is essential to optimize yield and productivity of navel orange, and reducing the environmental hazard.

\section{Irrigation management}

Most of the navel orange orchards in delta region irrigated by flooding system which used excessive quantities of water, this system and scheduling of irrigation require quickly change to improving productivity through reducing water consumption and decrease the loss of water and fertilizers.

Irrigation management practice could include the use of highefficiency irrigation systems, proper tools like soil moisture sensors, tensiometers, and weather data.

\section{Pest management}

Due to different reasons navel orange orchards infected with some pests and diseases affects trees productivity, i.e. Citrus Leafminer, Aphids, Asian Citrus Psyllids, various soft scales, Whiteflies, fruit flies, mealybugs, citrus thrips, citrus nematode, Phytophthora root rot, stubborn disease.
The appropriate pest management practice working in two ways:

1. Preventative method: including choosing rootstocks fewer susceptible to soil damage, removing weeds from orchards to reduce sources of different pests, using a proper irrigation system, development, and implementation of responsible farm management practices that enable growth of a healthy root system,

2. Chemically control: the primary management strategy currently depending on stimulating the proper handling of controlled using biological control, newer and safer pesticides, rather than harmful chemicals, and avoids Intensive chemical control. ${ }^{3}$

Integrated pest management could assist in reducing the pesticides and different infections, also, reduction of probable hazards to labors, consumers, and the environment through reduced fruit exposure.

\section{Pruning management}

Citrus trees have been pruned in different ways; some better than others, with respect to the traditional technique, which only removes dead, infected, weak wood, out of place branches.

Light is critically important for flowering and fruit set in citrus trees and considered the most critical factor controlling productivity of trees, in unpruned trees, light intensity decreased inside the canopy maybe $2 \%$ that of full sunlight which affects flower bud initiation, flowering, and fruit quality and tree growth. ${ }^{4}$

However, proper pruning and canopy management navel orange trees effects in productivity of vegetative growth that increased total yield and fruit quality.

The object of proper pruning is to encourage trees to produce a balance of vegetative and fruiting wood, with efficiently ventilated interior citrus canopy and small enough to harvest from the ground without the need for long rung ladder.

\section{Fruit harvest}

In delta region most of the citrus orchards harvesting manually for many years, however, nowadays there's increasing cost of harvesting operations due to labor shortages (manual harvesting of citrus fruit represents $35-45 \%$ approximately of total production cost), in the same time manual harvesting offers the benefits of determined fruit selection and full product quality, but has a relatively low picking rate.

Picking technique need development by providing mechanical harvesting methods to improve fruit quality and reduce harvesting cost. Mechanical harvesting offers a considerably greater harvesting rate over manual picking, the maximum picking rate of manual pickers is $0.5 \mathrm{t} / \mathrm{h}$, whereas the picking rate of trunk shaking harvesters is $10 \mathrm{t} / \mathrm{h} .^{5}$

\section{Weed control}

Due to usage of flooding irrigation system, there are different kind of weeds grow in citrus orchards in Delta region, mechanically control for weeds used after harvesting to reduce compete with the tree, and preparing rings manually around trees to avoid root damage and infection with root rot disease and other pathogens and regular removing before weed flowering to prevent seeds production. 
Preferable usage handy mowing for weeds after fruit set to reduce weed compete, during July weed could chopping again, to avoid different kinds of the grasshopper, also, some growers spray herbicide in the inter-rows escaping touching the plants, wherever, in other areas farmers' usage mulching materials to control weeds.

\section{Short plan for improving navel orange productivity in delta region}

1. Using some agricultural bio stimulants substances including, soil organic residues (humates compounds), yeast, and living microbes. ${ }^{6}$

2. Application of plant growth substances provides important economic benefits to citrus farmers dependent on the time of application and concentration.

3. Pruning: citrus tree needs full sun and light penetration all the year to get determined crops, so annual pruning open canopy for light and avoid crowding and shading.

4. The suitable quantity of irrigation water improves fruit quality and increase total yield.

5. Balanced fertilizing program formulated to deliver exact nutrient requirements for growth, predictable yield and fruit quality performance. $^{7}$

\section{Conclusion}

Improving Navel orange orchards productivity and fruit quality in Delta region depending on usage ofproper agricultural management practice like balanced nutrition, proper irrigation system; right pruning technique, using agricultural bio-stimulants, and integrated pest management.

\section{References}

1. Annual Reports of Statistical Institute and Agricultural Economic Research in Egypt. 2016.

2. Srivastava AK. Advances in Citrus Nutrition. 2012;369-389.

6. Grafton-Cardwell, Elizabeth E, Stelinski LL, et al. Biology and Management of Asian Citrus Psyllid, Vector of the Huanglongbing Pathogens. Annu Rev Entomol. 2013;58:413-432.

7. Fischler M, Goldschmidt EE, Monselise SP. Leaf area and fruit size on girdled grapefruit branches. J Amer Soc Hort Sci. 1983;108(2):218-221.

8. Sanders KF. Orange harvesting systems review. Bio-systems Engineering. 2005;90 (2): 115-125.

9. Abobatta W. Growth and Fruiting of Valencia orange trees. LAP LAMBERT Academic Publishing. 2015.

10. Zekri M. Factors affecting citrus production and quality. Citrus Industry. 2011. 